\title{
WDCP wt Allele
}

National Cancer Institute

\section{Source}

National Cancer Institute. WDCP wt Allele. NCI Thesaurus. Code C101429.

Human WDCP wild-type allele is located in the vicinity of 2 p23.3 and is approximately 20 $\mathrm{kb}$ in length. This allele, which encodes WD repeat and coiled-coil-containing protein, is involved in binding to tyrosine-protein kinase HCK. A tandem duplication that fuses this gene and the ALK gene may be associated with colorectal cancer. 